УДК 35.351/354

\title{
ПОГЛЯД НА ТИПОВУ НАВЧАЛЬНУ ПРОГРАМУ ПРЕДМЕТА «ЦИВІЛЬНИЙ ЗАХИСТ» ДЛЯ СТУДЕНТІВ ВНЗ
}

Старш. викл. В.А. Шемшур

\section{ВЗГЛЯД НА ТИПОВУЮ УЧЕБНУЮ ПРОГРАММУ ПРЕДМЕТА «ГРАЖДАНСКИЙ ЗАЩИТА» ДЛЯ СТУДЕНТОВ ВУЗ}

\author{
Старш. преп. В.А. Шемшур
}

\section{VIEW ON THE SUBJECT OF A MODEL CURRICULUM "CIVIL PROTECTION" FOR HIGH SCHOOL STUDENTS}

\section{V.A. Shemshur}

Кожна людина має невід'ємне право на життя. Ніхто не може бути свавільно позбавлений життя. Обов'язок держави - захищати життя людини.

Кожен має право захищати своє життя $i$ здоров'я, життя $i$ здоров'я інших людей від протиправних посягань.

(Стаття 27 Конституиії України).

Держава як гарант права людини на життя створила єдину державну систему иивільного захисту, однією з основних завдань якої є навчання населення поведінки та дій у разі виникнення надзвичайних ситуацій (HC).

Для реалізаџії ичих прав, вивчення обов'язків, визначення свого місия при НС Міністерством освіти $і$ науки, молоді та спорту Украӥни для ВНЗ за нормативною дисципліною «Цивільний захист» була запропонована нова Типова навчальна програма.

В статті розглянуті питання про деякі пункти змісту иієї програми, про можливість їх реалізачіï, визначені основні протиріччя, які виникають при безпосередній підготовиі кадрів технічного та інших профілів з даної дисципліни.

Висловлені пропозиції з удосконалення деяких питань Типової навчальної програми нормативної дисиипліни «Цивільний захист» для більш ефективного опанування курсу та можливостей практичного використання отриманих знань.

Ключові слова: ичивільний захист, Типова навчальна програма, змістові особливості.

Каждый человек имеет неотъемлемое право на жизнь. Никто не может быть произвольно лишен жизни. Обязанность государства - защищать жизнь человека.

Каждый имеет право защищать свою жизнь и здоровье, жизнь и здоровье других людей от противоправных посягательств.

(Статья 27 Конституции Украины).

Государство как гарант права человека на жизнь создало единую государственную систему гражданской защиты, одной из основных задач которой является обучение населения поведению и действиям в случае возникновения чрезвычайных ситуаций (ЧС).

Для реализачии этих прав, изучения обязанностей, определения своего места при ЧС Министерством образования и науки, молодежи и спорта Украины для ВУЗов по нормативной дисциплине «Гражданская защита» была предложена новая Типовая учебная программа. 
В статье рассмотрен вопрос о некоторых пунктах содержания этой программы, о возможности их реализации, определены основные противоречия, возникающие при непосредственной подготовке инженерных кадров технического и других профилей по данной дисциилине.

Высказаны предложения по усовершенствованию некоторых вопросов Типовой учебной программы нормативной дисчиплины «Гражданская Защита» для более эффрективного усвоения курса и возможностей практического использования полученньх знаний.

Ключевые слова: гражданская защита, Типовая учебная программа, существенные особенности.

Every person shall have the inalienable right to life. No one shall be arbitrarily deprived of life. Protection of human life shall be the duty of the State.

(Article 27 of the Constitution of Ukraine).

The State, as the guarantor of human right to life, has created the integrated state system of civil protection, one of the main goals of which is to teach the population how they should act and respond to emergencies.

To exercise these rights, study the responsibilities, determine one's role in emergencies the Ministry of Education and Science of Ukraine has proposed a new General Programme for higher educational establishments within the compulsory course 'Civil Protection'.

The article deals with several items of this programme and possibility to implement them, it defines main problems which can arise while preparing engineers of different fields within this course.

The article provides some proposals how to enhance The General Programme for the compulsory course 'Civil Protection' so that the students could completely master and more effectively implement the knowledge acquired.

Keywords: Educational programme on Civil Protection.

Метою вивчення дисципліни «Цивільний захист», згідно 3 Типовою навчальною програмою для ВН3, $\epsilon$ формування у студентів здатності творчо мислити, вирішувати складні проблеми інноваційного характеру й приймати продуктивні рішення у сфері цивільного захисту (ЦЗ) 3 урахуванням можливостей майбутньої професійної діяльності, а також досягнень науково-технічного прогресу.

Опанувавши навчальну програму дисципліни «Цивільний захист» студенти повинні бути здатними вирішувати професійні завдання 3 урахуванням вимог ЦЗ та володіти наступними професійними компетенціями для забезпечення реалізації вказаних завдань.

«Компетенція» в перекладі 3 латини означає коло питань, у яких людина добре обізнана, має знання та досвід. Які ж якості та знання необхідні студентові для того, щоб бути компетентним 3 питань цивільного захисту при майбутній професійній діяльності?

Розглядаючи деякі компетенції, які визначені Типовою навчальною програмою для студентів ВНЗ, і які повинні забезпечувати реалізацію вказаних завдань, слід проаналізувати та вирішити такі питання:

1. Вміння визначити коло своїх обов'язків за напрямом професійної діяльності з урахуванням завдань ЦЗ.

Опитування студентів перед початком занять 3 цієї дисципліни свідчить, що більшість 3 них вже забули або мають примарне уявлення про надзвичайні ситуації та їх наслідки, що вивчались на початкових курсах ВНЗ. Про обов'язки та функції держави в надзвичайних умовах, які можуть скластися, про існуючу 


\section{Підйомно-транспортні, дорожні, будівельні, меліоративні

Державну службу Цивільного захисту України, іiі призначення та завдання щодо захисту населення, надання допомоги постраждалим не мають ніякого уявлення взагалі.

Деякі питання безпеки існування людства, надання першої допомоги постраждалим передбачені програмою предмета «Безпека життєдіяльності» (БЖД), який викладається на початкових курсах у ВНЗ. Це принципи та проблеми забезпечення життєдіяльності, класифікація небезпечних факторів, надзвичайних ситуацій та ін. При вивченні предмета БЖД людина розглядається як частина (або складова) навколишнього середовища біологічний та соціальний суб'єкт, а піi діяльність - як активна взаємодія 3 цим середовищем. У розділі предмета БЖД про організацію та управління безпекою життєдіяльності запропоновані правові, нормативні, організаційні заходи для охорони праці, охорони навколишнього середовища, санітарного та протиепідемічного захисту, пожежної безпеки та кримінальна відповідальність за скоєні злочини. Передбачається й вивчення деяких статей Закону України «Про цивільний захист» та Женевської конвенції від 12 серпня 1949 р. щодо прав населення на захист свого життя та здоров'я від наслідків аварій, катастроф, стихійного лиха.

Однак цей предмет не передбачає вивчення функцій місцевих органів виконавчої влади, державної служби цивільного захисту, iī організаційної структури, відношення до них або взаємодію 3 ними цивільних осіб та визначення свого місця у разі виникнення надзвичайних ситуацій. Ці питання повинні бути вирішені при вивченні предмета «Цивільний захист», основою якого повинна бути реальна Типова навчальна програма з цієї дисципліни.

Вивчення дисципліни «Цивільний захист» повинно розпочатися з нагадування слухачам про різноманітність надзвичайних ситуацій, які вже вивчалися, визначення причин їх виникнення та про їх наслідки, що впливають на життєдіяльність людства та суспільство.

Якщо у слухачів немає чіткого уявлення про державну діяльність при $\mathrm{HC}$ та ii посадових осіб в місцевих органах виконавчої влади, про функції та обов'язки оперативних, аварійно-рятувальних служб цивільного захисту, про причетність до них громадян або взаємодію 3 ними, то при таких обставинах неможливо очікувати від них визначення свого місця, своєї поведінки, своїх обов'язків у мирний час, тим більш - в особливий період за напрямом майбутньої своєї професійної діяльності.

Без всебічного вивчення причин виникнення НС та їх наслідків, розуміння функцій державних органів виконавчої влади 3 питань їх подолання, загальної структури служби Цивільного захисту, іiі формувань та взаємодії з ними професійно вирішити завдання з урахуванням вимог ЦЗ молодому фахівцеві неможливо.

Для результативного вивчення предмета «Цивільний захист» 3 урахуванням відведеного на нього часу та опанування слухачами основних питань 3 цієї дисципліни Типова програма повинна передбачати більш конкретні теми для вирішення визначених завдань. До переліку тем занять потрібно включити вступний лекційний матеріал - історичну довідку про створення служби Ц3, сучасну організаційну структуру державної служби Ц3, iii завдання, правову базу та порядок комплектування iї підрозділів. Тільки після опанування такого матеріалу можна казати про можливість визначення свого місця, своїх прав та обов'язків молодим фахівцем у надзвичайних ситуаціях та вирішення ним професійних завдань 3 урахуванням вимог ЦЗ за напрямом майбутньої своєї професійної діяльності.

Обов'язки та особисті завдання на випадок НC повинні не визначатися студентом самостійно, як пропонує Типова програма, а бути вже визначеними в одній із тем робочої програми цивільного захисту 
ВН3. Розроблятися вони повинні для конкретних робочих місць, посад майбутніх молодих фахівців 3 урахуванням напряму їх професійної діяльності або бути загальними для деяких спеціальностей та рівнів посад керівної ланки.

В умовах реорганізаційних заходів, які доволі часто проводяться в Державній службі цивільного захисту України, іiі завдання та функції залишаються без значних змін, а організаційна структура змінюється несуттєво. Такі заходи не повинні впливати на Типову програму 3 основних питань ЦЗ для ВНЗ, підготовка в яких здійснюється за іншими напрямами. Така Типова програма при будь-яких змінах повинна бути більш конкретною для створення та розробки робочих програм 3 цієї дисципліни.

\section{2. Знання методів та інструмен- тарію моніторингу НС, побудови} моделей їх розвитку та оцінки їх соціально-економічних наслідків.

Надзвичайна ситуація завжди вимагає спочатку більш конкретних дій від керівництва та населення, що суттєво зменшує кількість жертв та матеріальних втрат. До робочої програми ВНЗ повинні бути включені не тільки теоретичні заходи, які передбачені Типовою програмою із засвоєння новітніх теорій, методів і технологій $з$ прогнозування НС, побудови моделей їхнього розвитку, оцінки їх соціально-економічних наслідків та ін. Спочатку повинні бути включені конкретні заходи, які передбачені на випадок НС місцевими органами виконавчої влади, місцевими службами ЦЗ та керівниками об’єктів. Типовою програмою повинно також передбачатися відпрацювання першочергових практичних дій згідно 3 планом ЦЗ району та самого об'єкта.

Що таке моніторинг? Це система збору, реєстрації, зберігання та аналізу невеликої кількості інформації про будьякий об'єкт для прийняття рішення про його стан. Ця інформація може бути використана для поліпшення процесу прийняття рішень, для інформування громадськості, для здійснення проектів, оцінки програм, вироблення політики та ін.

Моніторинг (згідно 3 визначенням) несе й організаційні функції - виявляс стан критичних або змінних явищ навколишнього середовища, забезпечус зворотний зв'язок щодо перемог або невдач визначеної політики або програм, встановлюс відповідність правилам та певним обставинам.

Про складність та різноманітність основних компетенцій, що пропонуються до освоєння Типовою програмою, свідчить лише простий перелік НC - природних i антропогенних явищ, які найчастіше трапляються у світі, при яких необхідно буде вирішувати складні питання з урахуванням своєї професійної діяльності. Це землетруси, повені, обвали, виверження вулканів, цунамі, пожежі, авто та авіакатастрофи, вибухи, епідемії, викиди радіаційних та хімічних речовин, засухи, морози та ін. У кожної з цих НС є свої причини, наслідки та характеристики. Звісно, що для моніторингу кожної 3 них повинен використовуватись відповідний інструментарій та застосовуватися відповідний метод іiі оцінки, прогнозування наслідків та ін.

Що ми бажаємо отримати від вживаного багатозначного слова «моніторинг» та від молодого фахівця випускника ВНЗ? Збирати та аналізувати інформацію, вивчати інструментарій, який використовується у кожному випадку, інформувати громадськість або виробляти якусь політику, здійснювати організаційні функції, працюючи за робочою спеціальністю або керівником початкової ланки?

Така компетенція, що запропонована Типовою програмою для слухачів, вимагає великої кількості навчального часу для їі опанування, який нею і не передбачений. На весь курс вивчення предмету 3 цивільного захисту виділяється всього 36 годин. Типова програма ЦЗ, яка запропонована ВН3, де підготовка фахівців здійснюється за іншими спеціальностями, 
більш притаманна ВН3, де підготовка фахівців здійснюється за спеціальностями Ц3. Від Типової програми предмета «Цивільний захист» у ВНЗ очікують більш конкретних та реальних підстав для розробки робочих програм, які б передбачали найголовніші питання в умовах обмеженого часу на їі викладання.

Щодо професійних компетенцій за видом діяльності:

заходи, які пропонується опанувати студентом:

- 3 прогнозування та оцінки обстановки;

- 3 надання характеристик осередків забруднення та ураження;

- 3 професійної оцінки радіаційної, хімічної та бактеріологічної обстановки;

- 3 розрахунку параметрів вражаючих чинників - джерел НC у випадку їх виникнення.

У сучасному житті такі заходи можуть бути проведені i будуть проводитись тільки кваліфікованими фахівцями, які мають відповідну освіту, досвід роботи у цьому напрямі, відповідне обладнання та робота яких у цьому напрямі $\epsilon$ їх основною діяльністю. Обладнання, яке застосовується у таких випадках, існує тільки в підрозділах оперативних та аварійно-рятувальних формувань цивільного захисту, а їх особовий склад має необхідний досвід з його використання.

На підприємствах і в організаціях державного сектора економіки, де планується майбутня робота випускників ВН3, а тим більш в комерційних структурах, як правило, таке обладнання відсутне, не кажучи вже про наявність необхідного досвіду його використання та виконання робіт, пов'язаних 3 прогнозуванням $\mathrm{HC}, \quad$ розрахунками вражаючих чинників та їх наслідків, наданням характеристик та ін.

Питання методики прогнозування, надання характеристик, професійної оцінки НС є фаховими і детально вивчаються та відпрацьовуються на практиці в організаціях та навчальних закладах, де підготовка фахівців ЦЗ $є$ основним напрямом підготовки або роботи. Визначені питання, які наявні у Типовій програмі цивільного захисту, у зв'язку із браком часу повинні мати тільки ознайомчий характер i обмежуватись вивченням приладів радіаційної, хімічної розвідки та дозиметричного контролю, як джерел первинних даних для проведення відповідних розрахунків.

Тому такі заходи, що пропонуються для вивчення в більшості організацій через відсутність матеріальної бази, яка нічим і не передбачена, відсутність досвіду роботи у цьому напрямі всебічно проводитись не будуть. Опанувавши у ВН3 ці заходи, молоді фахівці у подальшому не знайдуть ïх застосування у реальному житті, вони залишаться для них інформативними. В кращому випадку, у разі виникнення $\mathrm{HC}$ на підприємствах, установах та в організаціях їх керівництвом будуть проводитись заходи згідно з планом цивільного захисту об'єкта або під керівництвом місцевої виконавчої влади - спільні організаційні заходи 3 підрозділами цивільного захисту області, міста, району.

Основними питаннями для результативного вивчення предмета «Цивільний захист» також повинні бути:

- вивчення правової бази ЦЗ;

- вивчення керівних документів: типового плану цивільного захисту об'єкта, району, інструкцій на випадок НC;

- вивчення заходів щодо взаємодії 3 підрозділами аварійно-рятувальних служб;

- відпрацювання практичних дій з евакуації, збереження та захисту матеріальних цінностей та навколишнього середовища.

3 урахуванням того, що цивільний захист, перш за все, є функцією держави, яка спрямована на захист населення, територій, навколишнього середовища та майна від наслідків НС, Типова програма 3 цього предмету для ВНЗ повинна передбачати питання взаємодії з існуючими аварійно-рятувальними службами та 
місцевими органами виконавчої влади, питання самозахисту та порятунку, спрощені розрахунки прогнозування та оцінки радіаційної та хімічної обстановки. Інші питання цивільного захисту можуть бути включені до програми як інформативні при наявності навчального часу на їх вивчення.
Основні питання повинні викладатися реалістично 3 урахуванням умов та обставин, які складаються у теперішній час на даній місцевості, на даному об'єкті, в даний момент 3 урахуванням наявності сховищ, засобів індивідуального та колективного захисту, їх стану, обладнання та ін.

\section{Список використаних джерел}

1. Конституція України [Текст]; документ254к/96вр, чинний, поточна редакція. Тлумачення від 12.04.2012 р., підстава v009p710-12.

2. Кодекс Цивільного захисту України [Текст] // ВР України від 02.10.2012 p. № 5403 VI. Діє з 21.11.2012 p.

3. Типова навчальна програма нормативної дисципліни «Цивільний захист» для всіх спеціальностей за ОКР «спеціаліст», «магістр» [Текст]; затв. Заступником Міністра освіти і науки, молоді та спорту України Жебровським Б.М. 31.03.2011p.

Рецензент д-р техн. наук, професор М.І. Ворожбіян

Шемшур Володимир Анатолійович, старш. викл. кафедри охорони праці та навколишнього середовища.

Shemshur V.A. 